\title{
Eponyms in Gynecology and Obstetrics
}

\author{
Khalid Al Aboud ${ }^{1}$, Daifullah Al Aboud ${ }^{2}$
}

\section{INTRODUCTION}

Many of the terms used in Gynecology and Obstetrics are descriptive and they are derived from Latin or Greek. However, there other types of nomenclature used .For examples acronyms, such as "TORCH" [Toxoplasmosis, Others (HBV, syphilis, Varicella-Zoster virus, Epstein Barr virus, Coxsackie virus and Parvovirus), Rubella, Cytomegalovirus (CMV) and Herpes
Simplex $]^{1}$. Another example, is HELLP Syndrome, which is an acronym for Haemolysis, Elevated Liver enzyme levels and Low Platelet Count ${ }^{2}$.

Abbreviations are, also used .For examples, "PID" (Pelvic Inflammatory Disease), and "LMP" (Last Menstrual Period).

Eponym is a name derived from the name of a person ${ }^{3}$. There are several eponyms in Gynecology and Obstetrics literature. Some of these eponyms are old and some of them new. Some are no longer used while others are still in use. They are originated from different parts of the world.

Many doctors have no information about the history of eponyms. I this mini-review, we meant to shed some light on selected eponyms in Gynecology and Obstetrics (Table $1^{4-27}$ )

\begin{tabular}{|c|c|}
\hline \multicolumn{2}{|r|}{ Table 1: Selected Eponyms in Gynecology and Obstetrics } \\
\hline $\begin{array}{l}\text { Eponyms in } \\
\text { Gynecology and } \\
\text { Obstetrics }\end{array}$ & Remarks \\
\hline \multirow[t]{2}{*}{ Apgar score $^{4}$} & $\begin{array}{l}\text { This is a famous score used to assess the health of newborn children immediately after birth. Apgar score ranges from } \\
\text { zero to 10. The five criteria are summarized using words chosen to form a backronym (Appearance, Pulse, Grimace, } \\
\text { Activity, and Respiration). }\end{array}$ \\
\hline & Named after an American obstetrical anesthesiologist, Virginia Apgar (1909-1974), (figure.1). \\
\hline \multirow{2}{*}{$\begin{array}{l}\text { Braxton Hicks } \\
\text { contractions }^{5,6}\end{array}$} & These are sporadic uterine contractions that sometimes start around six weeks into a pregnancy. \\
\hline & $\begin{array}{l}\text { Named after, John Braxton Hicks (1823 - 1897), (figure.2), who was a 19th-century English doctor who specialized in } \\
\text { obstetrics. }\end{array}$ \\
\hline \multirow[t]{3}{*}{ Brenner tumors 7,8} & Brenner tumors are uncommon tumors that are part of the surface epithelial-stromal tumor group of ovarian neoplasms. \\
\hline & $\begin{array}{l}\text { The majority of these tumors are benign. It is named for Fritz Brenner ( 1877- 1969), (figure.3), who was a German } \\
\text { physician and pathologist. }\end{array}$ \\
\hline & $\begin{array}{l}\text { In } 1935 \text { Brenner migrated to South Africa. It was whilst he was in Johannesburg that he was surprised to learn that his } \\
\text { name was eponymously attached to the tumor. }\end{array}$ \\
\hline Cullen sign ${ }^{9}$ & $\begin{array}{l}\text { Periumbilical ecchymosis in cases of acute hemorrhagic pancreatitis and ruptured ectopic pregnancy is termed Cullen's } \\
\text { sign. Similar changes in the flank are called as Grey-Turner sign. Thomas Stephen Cullen (1868-1953), (figure. 4), was } \\
\text { a Canadian gynecologist associated with Johns Hopkins Hospital. }\end{array}$ \\
\hline Fallopian tube $\mathrm{e}^{10}$ & $\begin{array}{l}\text { This known anatomical structure is named after, Gabriele Falloppio (1523-1562), (figure.5), who was an Italian } \\
\text { anatomist. It is said that throughout the doctor's life, he discouraged the use of his name to describe the invention. } \\
\text { Falloppio was a keen botanist and the plant genus «fallopia» is named after him. }\end{array}$ \\
\hline $\begin{array}{l}\text { Fitz-Hugh and Curtis } \\
\text { syndrome }^{11-13}\end{array}$ & $\begin{array}{l}\text { This is a rare complication of pelvic inflammatory disease (PID) named after the two physicians, Thomas Fitz-Hugh, Jr } \\
\text { and Arthur Hale Curtis . Arthur Hale Curtis (1881-1955), (figure.6), was an American gynecologist. Thomas Fitz-Hugh, } \\
\mathrm{Jr} \text { (1894- 1963), (figure.7), was an American physician. }\end{array}$ \\
\hline
\end{tabular}

\footnotetext{
1 Department of Public Health, King Faisal

Hospital, Makah, Saudi Arabia

2 Dermatology department, Taif University,

Taif, Saudi Arabia
} 


\begin{tabular}{|c|c|}
\hline Gartner cyst ${ }^{14}$ & $\begin{array}{l}\text { It is usually an asymptomatic vaginal cyst, which develops from the wolffian duct remnants in the vaginal wall .Named } \\
\text { after, Hermann Treschow Gartner (1785-1827), who was a Danish surgeon and anatomist. }\end{array}$ \\
\hline Gaskin maneuver ${ }^{15}$ & $\begin{array}{l}\text { Also, known as all-fours maneuver .It consists of moving the laboring patient to her hands and knees. This technique } \\
\text { is used for reducing shoulder dystocia in laboring women. It is named after, Ina May Gaskin, (figure.8), an American } \\
\text { Midwife. }\end{array}$ \\
\hline $\begin{array}{l}\text { Hydatids of } \\
\text { Morgagni }{ }^{16-18}\end{array}$ & $\begin{array}{l}\text { These are pedunculated, cystic structures arising from müllerian vestiges below the fallopian tube near the fimbria. } \\
\text { They usually are of no clinical significance unless the pedicle becomes twisted and infarction occurs. Giovanni } \\
\text { Battista Morgagni (1682-1771), (figure.9), was an Italian anatomist. }\end{array}$ \\
\hline Kegel exercises ${ }^{19}$ & $\begin{array}{l}\text { It refers to pelvic floor exercise, used for the treatment of many urogynecological disorders including urinary } \\
\text { incontinence. Arnold Henry Kegel (1894 - 1981), (figure.10) was an American gynecologist. }\end{array}$ \\
\hline Krukenberg's tumor ${ }^{20,21}$ & $\begin{array}{l}\text { A malignant tumor of the ovary, usually bilateral, with fibromyxomatous stroma and scattered mucin secreting signet } \\
\text { cells .Named after, a German gynecologist and pathologist, Friedrich Ernst Krukenberg (1871-1946). }\end{array}$ \\
\hline Meigs syndrome $e^{22-24}$ & $\begin{array}{l}\text { It refers to the presence of ascites with hydrothorax in association with benign ovarian tumor. It is named for Joe } \\
\text { Vincent Meigs (1892-1963), (figure.11), a Harvard Medical School Professor of Gynecology. }\end{array}$ \\
\hline Papanicolaou's smear ${ }^{25}$ & $\begin{array}{l}\text { Also called Pap test and Pap smear. It is a cytodiagnostic test for early detection of cervical cancer. Named after } \\
\text { George Nicholas Papanicolaou (1883-1962), (Figure. 12), who was a Greek-American cytologist and pathologist. }\end{array}$ \\
\hline Sheehan's syndrome ${ }^{26}$ & $\begin{array}{l}\text { It refers to postpartum necrosis of the anterior pituitary gland, occurring as consequence of ischemia after severe } \\
\text { puerperal hemorrhage. It is named for Harold Leeming Sheehan (1900-1988), (figure.13), who was an English } \\
\text { pathologist. }\end{array}$ \\
\hline \multirow[t]{2}{*}{$\begin{array}{l}\text { Stein-Leventhal } \\
\text { syndrome }\end{array}$} & $\begin{array}{l}\text { This is another name for polycystic ovarian syndrome (PCOS) .A condition characterized by menstrual dysfunction, } \\
\text { anovulation, and signs of hyperandrogenism. }\end{array}$ \\
\hline & $\begin{array}{l}\text { It is named after, Irving Freiler Stein (1887-1976), (figure.14), who was an American gynecologist and his colleague, } \\
\text { Michael Leo Leventhal (1901-1971), (figure.15). }\end{array}$ \\
\hline
\end{tabular}

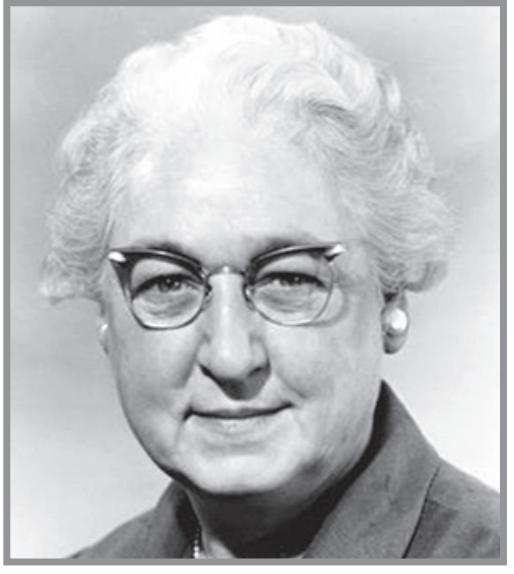

Virginia Apgar (1909-1974)

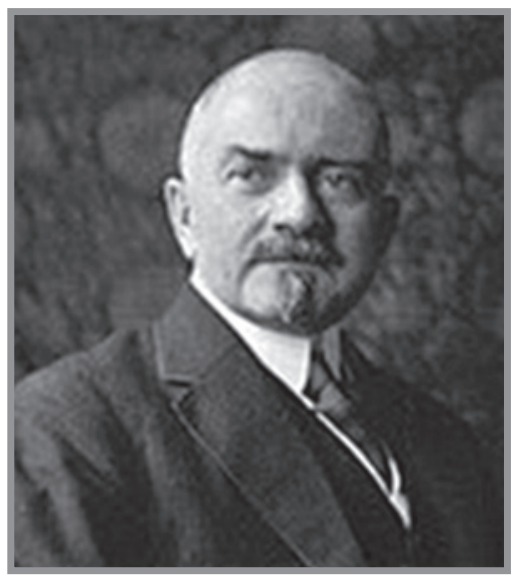

Thomas Stephen Cullen (1868-1953)

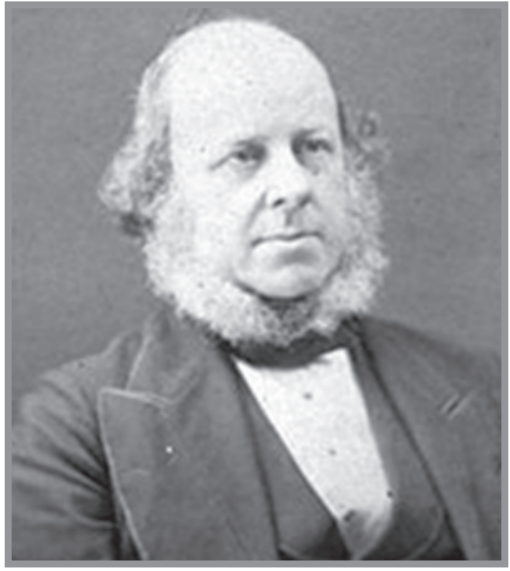

John Braxton Hicks (1823-1897)

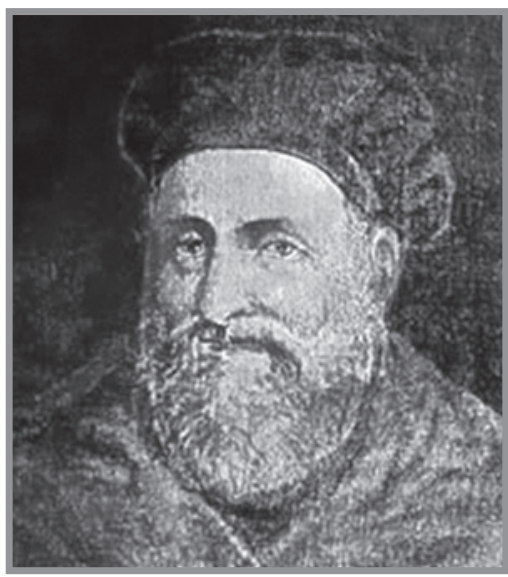

Gabriele Falloppio (1523-1562)

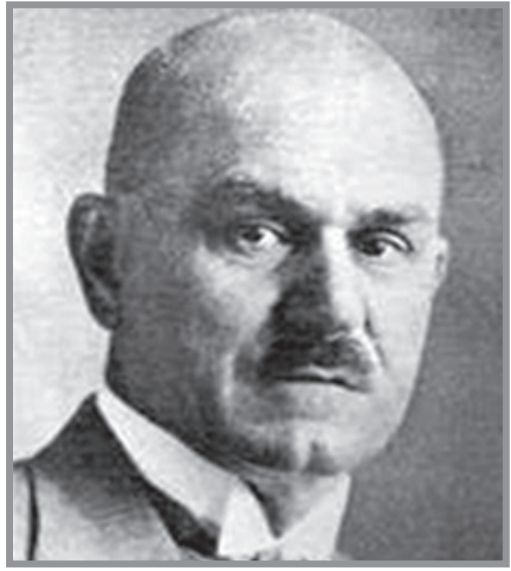

Fritz Brenner (1877-1969)

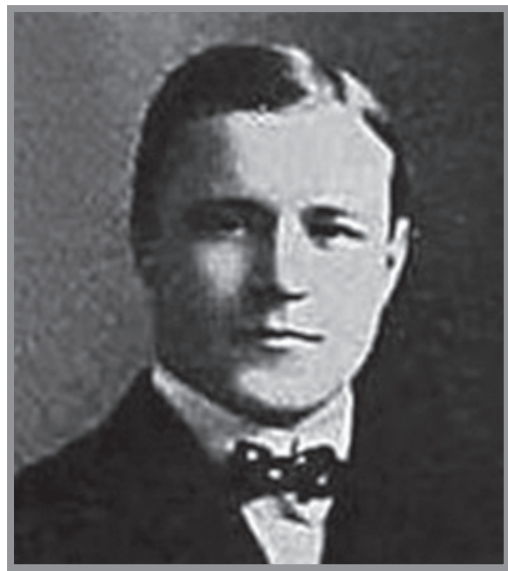

Arthur Hale Curtis (1881 -1955) 


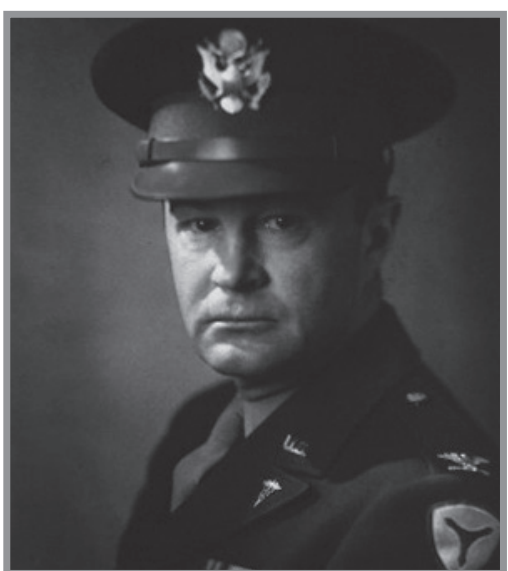

Thomas Fitz-Hugh, Jr (1894-1963)

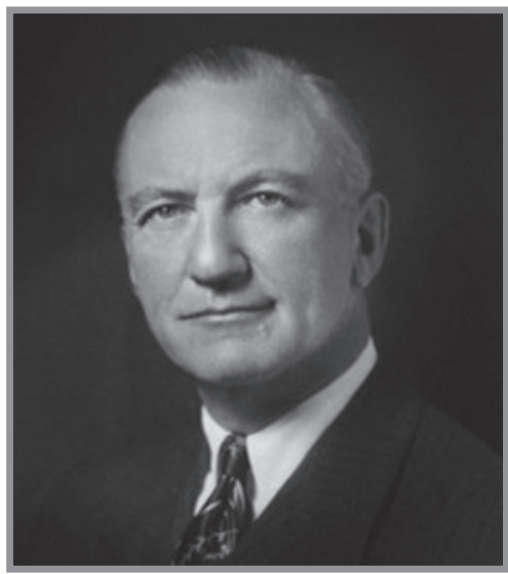

Arnold Henry Kegel (1894-1981)

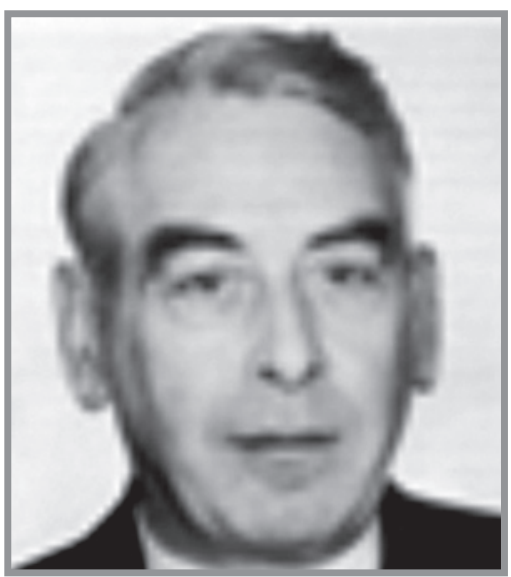

Harold Leeming Sheehan (1900-1988)

\section{REFERENCES}

1. De Carolis S, Santucci S, Botta A, Salvi S, Degennaro VA, Garufi C, Garofalo S, Ferrazzani S, Scambia G. The relationship between TORCH complex false positivity and obstetric outcome in patients with antiphospholipid syndrome. Lupus 2012; 21(7):773-5.

2. Ogu RN .Inimgba NM, Jamabo RS.

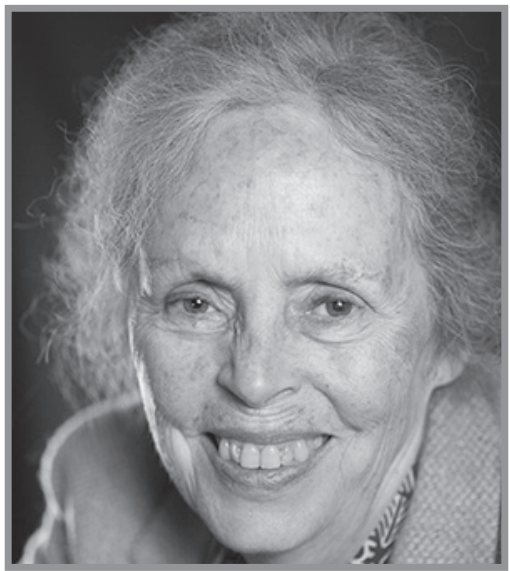

Ina May Gaskin (1940- )

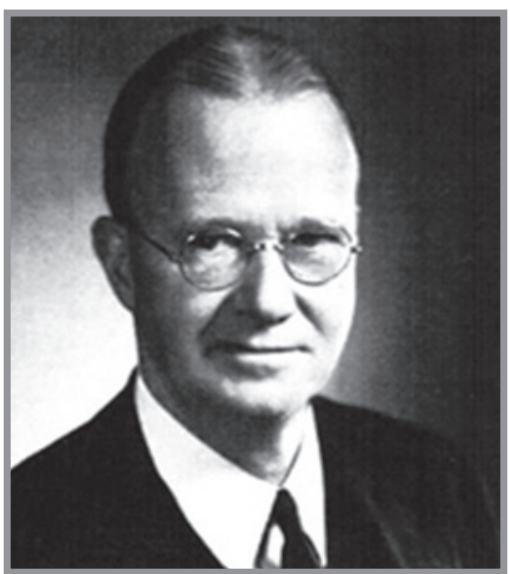

Joe Vincent Meigs (1892-1963)

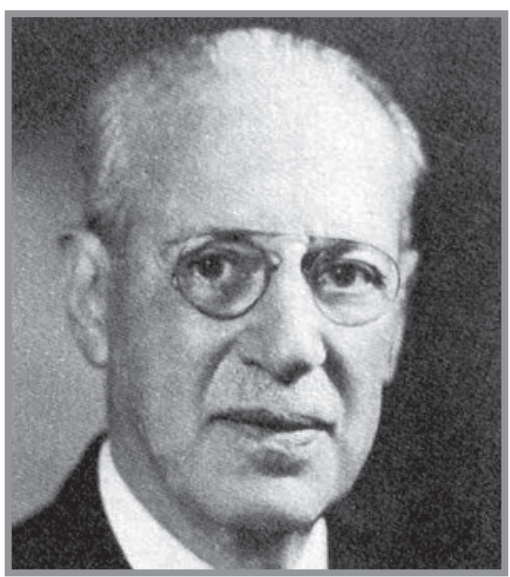

Irving Freiler Stein (1887-1976)

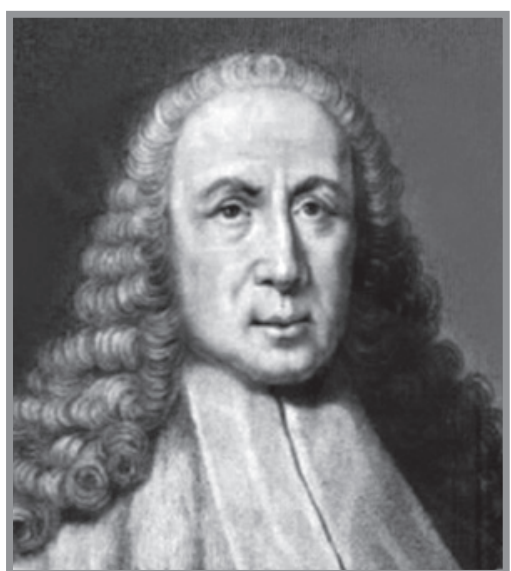

Giovanni Battista Morgagni (1682-1771)

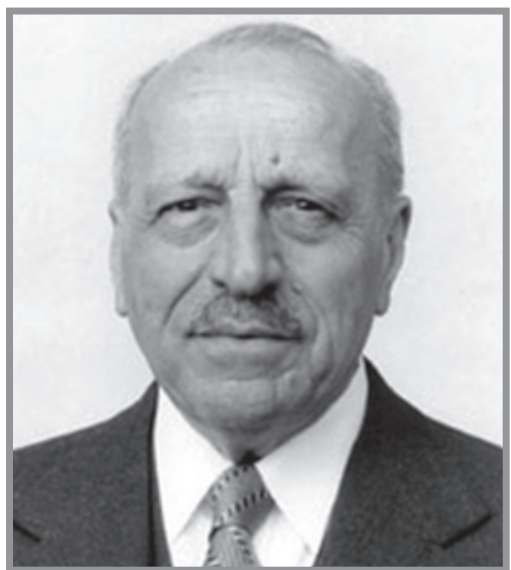

George N Papanicolaou (1883-1962)

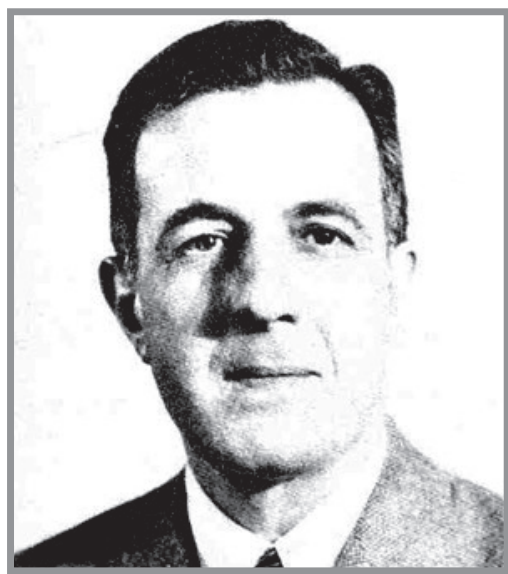

Michael Leo Leventhal (1901-1971)
HELLP syndrome: a report of two cases. Niger J Med 2005; 14(3):322-4.

3. Jana N, Barik S, Arora N. Current use of medical eponyms--a need for global uniformity in scientific publications. BMC Med Res Methodol 2009; 9:18.

4. van Gijn J, Gijselhart JP. [Virginia Apgar and her scale]. Ned Tijdschr Geneeskd 2012; 156(1):A4031.
5. Dunn PM.John Braxton Hicks (1823-97) and painless uterine contractions. Arch Dis Child Fetal Neonatal Ed. 1999 Sep; 81(2):F157-8.

6. Hill WC, Lambertz EL. Let's get rid of the term "Braxton Hicks contractions". Obstet Gynecol 1990; 75(4):709-10.

7. Speert H. Obstetrical-gynecological eponyms: Fritz Brenner and Brenner 
tumors of the ovary. Cancer 1956; 9(2):217-21.

8. Fox RA. Brenner tumor of the ovary: Case reports, discussion and bibliography. Am J Pathol 1942; 18(2):223-35.

9. Al Aboud K, Al Aboud A. Eponyms linked to „signs” in the dermatology literature. Our Dermatol Online 2013; 4(4): 579581.

10. van Gijn J, Gijselhart JP. [Falloppius and his uterine tubes]. Ned Tijdschr Geneeskd. 2011; 155(51):A3639.

11. Fitz-Hugh Jr T.Acute gonococcic peritonitis of the right upper quadrant in women. Journal of the American Medical Association, Chicago 1934; 102: 20942096.

12. Curtis AH. A cause of adhesion in the right upper quadrant. Journal of the American Medical Association, Chicago 1930; 94: 1221-122.

13. Ravdin IS. Memoir of Thomas FitzHugh, JR.-1894-1963. Trans Stud Coll Physicians Phila 1965; 32:179-80.

14. Bats AS, Metzger U, Le Frere-Belda
MA, Brisa M, Lecuru F. Malignant transformation of Gartner cyst. Int J Gynecol Cancer. 2009; 19(9):1655-7.

15. Gaskin IM. For the first time in history an obstetrical maneuver in named after a midwife. Birth Gaz 1998; 14(3):50.

16. Clivio I.[Morgagni and his obstetrical and gynecological observations].Ann Ostet Ginecol 1952; 74(1):3-28.

17. Speert $H \quad$.Obstetric-gynecologic eponyms; Giovanni Battista Morgagni and the hydatids of the broad ligament. Am J Clin Pathol 1955; 25(12):1341-8.

18. Wittich AC.Hydatid of morgagni with torsion diagnosed during cesarean delivery. A case report. J Reprod Med 2002; 47(8):680-2.

19. Di Benedetto P. Female urinary incontinence rehabilitation. Minerva Ginecol 2004; 56(4):353-69.

20. Speert H .Obstetrical-gynecological eponyms: Freidrich Krukenberg and ovari an tumors. Cancer 1955; 8(5):869-71.

21. Flam $F$, Larson $B$, Silfverswärd $C$. [The man behind the tumor: Friedrich
Krukenberg. He described metastasis to the ovaries]. Lakartidningen 1993; 90(24):2311-2.

22. Rowlands BC, Garrett JV, King PA.Meigs' syndrome: a brief review of the condition and report of a case associated with a Brenner tumour. Br J Surg 1954; 41(170):645-8.

23. Powell JL. Powell's Pearls: Joe Vincent Meigs, MD (1892-1963). Obstet Gynecol Surv 2006; 61(12):753-4.

24. Lurie S.Meigs' syndrome: the history of the eponym. Eur J Obstet Gynecol Reprod Biol $2000 ; 92(2): 199-204$.

25. Al Aboud K, Al Aboud A. Eponyms in the dermatology literature linked to Greece. Our Dermatol Online 2013; 4(Suppl. 2): 435-436.

26. Tessnow AH, Wilson JD. The changing face of Sheehan's syndrome. Am J Med Sci 2010; 340(5):402-6.

27. Dastur Adi E, Tank P D. Irving Stein,Michael Leventhal and a slice of endocrine history. J Obstet Gynecol India 2010; 60 (2): 121-122. 